\title{
KONSELING DENGAN TEKNIK DEMONSTRASI UNTUK MENINGKATKAN KEMAMPUAN TOILET TRAINING PADA ANAK
}

\author{
Andri Kusuma Wijaya ${ }^{1 *}$, Nurhayati ${ }^{2}$, Fatsiwi Nunik Andari ${ }^{3}$, Wenti Dewentri ${ }^{4}$ \\ ${ }^{1}$ Dosen Program Studi IImu Keperawatan UM Bengkulu \\ Email: andrikwijaya@umb.ac.id \\ ${ }^{2}$ Dosen Program Studi Ilmu Keperawatan UM Bengkulu \\ Email: nurhayati@umb.ac.id \\ ${ }^{3}$ Dosen Program Studi Profesi Ners UM Bengkulu \\ Email: fatsiwiandari@umb.ac.id \\ ${ }^{4}$ Mahasiswa Program Studi IImu Keperawatan UM Bengkulu \\ Email: wentidewentri@gmail.com
}

Disubmit: 30 Desember $2021 \quad$ Diterima: 31 Desember $2021 \quad$ Diterbitkan: 03 Januari 2022 DOI: https://doi.org/10.33024/mnj.v1i1.5744

\section{ABSTRACT: COUNSELING WITH DEMONSTRATION TECHNIQUES TO IMPROVE ABILITY TOILET TRAINING FOR CHILDREN}

\begin{abstract}
Toilet training is a form of business carried out with the aim of controlling defecation (chapters) and urination (tub) which is carried out in children, this activity is carried out with the hope that children are able to prevent the occurrence of delays in controlling chapters and tubs. Children need to get attention, especially in the elements of growth and development that are carried out from the beginning of child development. So that the formation of children with abilities and qualities with great categories will achieve the future of children with superior categories so as to produce healthy and intelligent children.
\end{abstract}

Objective: The purpose of this study was to determine the effect of demonstration technique counseling to improve toilet training abilities in children. Methods: This research was conducted with a quantitative type of research where the design used was a pre-experimental design using the One Group Pre-Test and Post-Test approaches.

Results: The univariate results of this study obtained the characteristics of respondents from 15 respondents, most of the respondents, namely 11 respondents (73.3\%) were at the age of 5 years. For the results of the bivariate analysis using the Wilcoxon Signed Ranks Test statistical test, the $p$ value (value) $=0.001<0.05$.

Conclusion: the conclusion of this study is that there is an effect of counseling with demonstration techniques to improve toilet training abilities in children.

Keywords: Counseling, Demonstration, Toilet Training

\section{INTISARI: KONSELING DENGAN TEKNIK DEMONSTRASI UNTUK MENINGKATKAN KEMAMPUAN TOILET TRAINING PADA ANAK}

Pendahuluan: Toilet training ialah suatu bentuk usaha yang dilakukan dengan tujuan mengontrol buang air besar (bab) dan buang air kecil (bak) yang dilaksanakan pada anak, kegiatan ini dilakukan dengan harapan anak mampu mencegah terjadinya kondisi keterlambatan mengontrol bab dan bak. Anak perlu 
mendapatkan perhatian terutama dalam unsur tumbuh kembangnya yang dilakukan sejak awal perkembangan anak. Sehingga akan terbentuknya anakanak dengan kemampuan dan kualitas dengan kategori hebat sehingga akan tercapainya masa depan anak dengan kategori unggul sehingga menghasilkan anak-anak yang sehat dan cerdas.

Tujuan: Tujuan penelitian ini diketahui pengaruh konseling teknik demonstrasi untuk meningkatkan kemampuan toilet training pada anak.

Metode: Penelitian ini dilakukan dengan jenis penelitian kuantitatif dimana desain yang digunakan ialah dengan desain pra eksperimen dengan menggunakan pendekatan One Group Pre-Test dan Post-Test.

Hasil: Hasil univariat dari penelitian ini didapatkan karakteristik responden dari 15 responden sebagian besar responden yaitu 11 responden $(73,3 \%)$ berada pada usia 5 tahun. Untuk hasil analisis bivariat dengan menggunakan uji statistik Wilcoxon Signed Ranks Test diperoleh nilai p (value) $=0,001<0,05$.

Kesimpulan: kesimpulan penelitian ini ialah ada pengaruh konseling dengan teknik demonstrasi untuk meningkatkan kemampuan toilet training pada anak.

Kata kunci: Konseling, Demonstrasi, Toilet training

\section{PENDAHULUAN}

\begin{tabular}{lll}
\multicolumn{1}{c}{ Toilet } & Training & merupakan \\
tindakan & untuk & mengontrol \\
pembuangan & kotoran pada anak,
\end{tabular} yang tersusun dari sistem saluran kemih dan kotoran. Jamban salah satu persiapan yang harus ada ketika ada keinginan untuk bab dan bak, tahapan lain yang harus dipersiapkan ialah pakaiannya, baru dilanjutkan dengan melakukan miksi dan bab, kemudian membersihkan dirinya sekali lagi, serta menggunakan kembali pakaian yang telah dilepas (Khoiruzzadi \& Fajriyah, 2019).

Di Negara Amerika Serikat anak dengan usia 24 bulan terdapat sekitar $26 \%$ mengalami permasalahan mengompol sementara anak usia 30 bulan ada sekitar $88 \%$ mengalami kondisi mengompol sementara $98 \%$ terjadi pada usia 36 bulan. Hal lain juga terjadi pada Negara Inggris dimana $1,3 \%$ terjadi pada anak putra dan $0,3 \%$ terjadi pada anak putri yang melakukan buang air besar (bab) dan buang air kecil (bak) di tempat yang tidak sesuai dengan tempatnya dimana kondisi ini berlangsung hingga usia anak 7 tahun, kondisi ini disebabkan oleh kurangnya persiapan pemahaman terkait jamban atau toilet training (Utami et al., 2020).

Negara Indonesia pada tahun 2017 memperlihatkan bahwa jumlah balita pada tahun 2016 terdapat 30\% dari 258.704.986 penduduk Indonesia. Diantaranya terdiri dari 75 juta dengan usia anak yang masuk kekategori usia prasekolah yang mengalami kondisi ketidakmampuan dalam mengontrol bab dan bak, kondisi ini terjadi oleh karena sejak tahap awal anak tidak dilatih memahami konsep toilet training yang idealnya dilakukan secara mandiri. Negara Indonesia juga ada $50 \%$ (52.226) kasus dengan masalah mengompol yang terjadi pada anak yang dilihat dari riwayat keluarga (Utami et al., 2020).

Sementara menurut Survey Kesehatan Rumah Tangga (SKRT) diperkirakan di Indonesia terapat anak dengan ketidakmampuan mengontrol bab dan bak dari usia tooddler sampai prasekolah berjumlah sampai 75 juta (Wasliah, 2020).

Data hasil penelitian terakhir yang dilaksanakan di kota Bengkulu 
di mana ada 81 anak yang di ambil sebagai sampel dalam kegiatan penelitian dengan tingkat kemampuan anak dalam melaksanakan toilet training berada pada kategori rendah dimana kondisi ini disebabkan oleh masih adanya kegagalan anak dalam melakukan toilet training, keadaan ini juga di pengaruhi karena adanya faktor dalam hal ini kurangnya pengetahuan dan sikap ibu atau orang tua yang tidak mengetahui terkait toilet training, serta tingkatan pendidikan yang rendah dan mempengaruhi terlaksananya toilet training sejak usia dini sehingga tidak mampu mengajarkan kemandirian toilet training pada anak, penelitian ini menghasilkan 41 anak berada pada ketegori kurang mampu dalam melakukan toilet training (Buston, 2018).

Untuk meningkatkan kemampuan toilet training khususnya pada anak ada beberapa intervensi yang dapat dilakukan salah satunya adalah konseling teknik demonstrasi untuk melatih toilet training pada anak. Teknik demontrasi ini ialah tempat untuk melatih pemahaman dan pengalaman belajar sehingga harapan akhirnya anak mampu memahami dan menguasai materi pembelajaran secara lebih baik. Teknik ini mampu membuat anak belajar secara langsung dan mengikuti instruksi pendidik sehingga anak dengan mudah mampu mempraktekan cara toilet training yang benar (Kiftiyah et al., 2018).

Studi pendahuluan yang dilakukan oleh peneliti pada bulan April 2021 di TK Lembayung Indah Kota Bengkulu, dimana dari 15 anak hanya 6 orang anak yang mampu melakukan atau membersihkan diri setelah kegiatan bak dan bab. Hasil wawancara kepada orang tua juga diketahui bahwa belum pernah mendapatkan konseling terkait pemahaman toilet training yang baik dan benar apa lagi melihat secara langsung praktek tindakan tersebut.

Berdasarkan penjelasan diatas maka dalam hal ini membuat peneliti tertarik untuk mengetahui tentang pengaruh konseling dengan teknik demonstrasi dalam meningkatkan kemampuan toilet training anak di TK Lembayung Indah Kota Bengkulu.

\section{METODE PENELITIAN}

Penelitian ialah penelitian kuantitatif dimana eksplorasi spesifik yang menggunakan banyak angka, mulai dari ragam informasi, pemahaman informasi, dan adanya hasil (Sugiyono, 2013). Desain penelitian yang digunakan dalam penelitian ini adalah desain pra eksperimen menggunakan rancangan penelitian one group pre-test dan post-test dimana penelitian ini dilaksanakan pada hanya satu group atau kelompok tanpa adanya group atau kelompok pembanding (Zulmiyetri et al., 2020).

Populasi dalam penelitian ini adalah ialah merupakan anak didik di TK Lembayung Indah Kota Bengkulu. Populasi dalam penelitian ini berjumlah sebanyak 22 orang peserta didik. Tekhnik sampel yang digunakan dalam penelitian ini dengan menggunakan tehnik purpose sampling yaitu metode pengambilan sampel dengan kriteria-kriteria tertentu. Sampel yang digunakan dalam penelitian ini adalah anak didik di TK Lembayung Indah Kota Bengkulu yang berjumlah 15 orang.

Adapun prosedur penelitian yang dilakukan dalam penelitian ini dimulai dari mengurus surat izin penelitian, kemudian peneliti mendatangi responden satu-persatu, peneliti menjelaskan pada anak dan ibunya tentang intervensi yang akan di lakukan, peneliti meminta persetujuan serta kesediaan 
responden atau ibunya yang mendampinginya untuk melakukan kegiatan toilet training. Tahap selanjutnya melakukan latihan toilet training dengan memastikan kondisi aman, kemudian mulai latihan dengan menjalin komunikasi yang baik dengan anak supaya lathan berjalan dengan lancar serta di dampingi oleh orang terdekatnya, ajarkan anak cara membuka celana/rok, lalu ajarkan anak cara duduk di atas potty/kloset, selanjutnya ajarkan anak cara membersihkan diri/cebok sampai bersih, ajarkan anak berdiri dari kloset, kemudian ajarkan anak cara menyiram kloset sampai bersih dan cara mengeringkan bagian tubuh yang basah dengan lap/tisu, lanjut ajarkan anak cara memakai celana/rok kembali serta ajarkan anak cara mencuci tangan dengan sabun setelah selesai dari toilet dan mengeringkannya.

Setelah melakukan intervensi konseling dengan teknik demontrasi toilet training, kemampuan toilet training anak di ukur kembali dengan menggukan instrumen penelitian. Instrument penelitian yang digunakan untuk pengumpulan data yaitu menggunakan lembar observasi kuesioner dimana lembar tersebut berisi pertanyaan terkait tingkat kemampuan anak dalam melakukan toilet training. Berdasarkan hasi uji normalitas data diketahui data posttest tidak berditribusi normal. Hasil dari penelitian ini dilakukan analisis data baik itu analisis univariat maupun analisis bivariat dimana dalam penelitian ini analisis bivariat diuji dengan menggunakan uji Wilcoxon Signed Ranks Test untuk mengetahui pengaruh konseling tehnik demonstrasi terhadap peningkatan kemampuan toilet training pada anak.
HASIL

Analisis Univariat

Analisis univariat dilakukan untuk mendapatkan data karateristik responden.

Tabel 1

Distribusi Frekuensi Usia Anak

Di TK Lembayung Indah Kota Bengkulu

\begin{tabular}{lcc}
\hline $\begin{array}{l}\text { Karakteristik } \\
\text { Responden }\end{array}$ & $\mathbf{F}$ & $\mathbf{P ~ ( \% )}$ \\
\hline Usia & & \\
\hline 3 Tahun & 0 & 0 \\
\hline 4 Tahun & 1 & 6,7 \\
\hline 5 Tahun & 11 & 73,3 \\
\hline > 5 Tahun & 3 & 20 \\
\hline \multicolumn{1}{c}{ Total } & 15 & 100 \\
\hline
\end{tabular}

Berdasarkan Tabel 1 diketahui bahwa dari 15 responden sebagian besar responden yaitu 11 responden $(73,3 \%)$ berada pada usia 5 Tahun.

Tabel 2

Distribusi Tingkat Kemampuan

Toilet Training Anak Sebelum di Lakukan Intervensi

\begin{tabular}{lcc}
\hline $\begin{array}{c}\text { Toilet Training } \\
\text { Sebelum }\end{array}$ & $\mathbf{F}$ & $\mathbf{P}$ (\%) \\
\hline Keterlambatan & 12 & 80,0 \\
\hline Berhasil & 3 & 20,0 \\
\hline Total & 15 & 100,0 \\
\hline
\end{tabular}

Berdasarkan Tabel 2 di atas sebagian besar responden yaitu 12 orang $(80,0 \%) \quad$ mengalami keterlambatan toilet training sebelum dilakukan intervensi konseling dengan teknik demonstrasi.

Tabel 3

Distribusi Tingkat Kemampuan Toilet Training Anak Setelah di Lakukan Intervensi

\begin{tabular}{lcc}
\hline $\begin{array}{c}\text { Toilet Training } \\
\text { Setelah }\end{array}$ & $\mathbf{F}$ & $\mathbf{P ~ ( \% )}$ \\
\hline Keterlambatan & 0 & 0,0 \\
\hline Berhasil & 15 & 100,0 \\
\hline Total & 15 & 100,0 \\
\hline
\end{tabular}


Berdasarkan Tabel 3 di atas seluruh responden yaitu 15 orang $(100,0 \%)$ mengalami keberhasilan toilet training setelah dilakukan intervensi konseling dengan teknik demonstrasi.

\section{Analisa Bivariat}

Analisis bivariat dilakukan untuk mendapatkan data terkait hasil analisis pengaruh pemberian intervensi konseling dengan tehnik demonstrasi terhadap kemampuan toilet training pada anak dengan menggunakan uji statistik Wilcoxon Signed Ranks Test. Tabel 4

Pengaruh Konseling Dengan Teknik Demonstrasi Terhadap Kemampuan Toilet Training Anak Di TK Lembayung Indah Kota Bengkulu

\begin{tabular}{ccc|c}
$\begin{array}{c}\text { Post Test- } \\
\text { Pre Test }\end{array}$ & $\mathbf{N}$ & $\begin{array}{c}\text { Mean } \\
\text { Rank }\end{array}$ & P \\
\cline { 1 - 3 } $\begin{array}{c}\text { Negatif } \\
\text { Ranks }\end{array}$ & 0 & 0 & \multirow{2}{*}{0,001} \\
\cline { 1 - 2 } $\begin{array}{c}\text { Positive } \\
\text { Rangks }\end{array}$ & 12 & 6,50 & \\
\cline { 1 - 2 } Ties & 3 & & \\
\cline { 1 - 2 } Total & 15 & & \\
\hline
\end{tabular}

Berdasarkan Tabel 4 di atas

diketahui bahwa Hasil uji statistik Wilcoxon Signed Ranks Test dengan nilai $\mathrm{p}$ (value) $=0,001$ yang berarti $<0,05$, maka dapat ditarik kesimpulan bahwa dalam ada pengaruh konseling dengan teknik demonstrasi dalam meningkatkan kemampuan toilet training anak di TK Lembayung Indah Kota Bengkulu.

\section{PEMBAHASAN}

\section{Analisis Univariat}

Karakteristik

\section{Berdasarkan Usia}

\section{Responden}

Berdasarkan tabel 1 terkait hasil penelitian univariat diketahui dari 15 responden sebagian besar responden yaitu 11 responden $(73,3 \%)$ dengan usia pada rentan 5 tahun, 1 responden berusia 4 tahun
$(6,7 \%)$ dan 3 anak berusia $>5$ tahun (20,0\%)

Hasil penelitian ini sejalan dengan (Soediono, 2014) yang menjelaskan bahwa batasan usia anak adalah mulai anak berada dalam kandungan sampai anak berusia 19 tahun. sehingga semua kategori usia yang berada di TK Lembayung Indah Kota Bengkulu benar-benar responden yang masuk kedalam kategori anak.

\section{Penelitian} lain juga mengungkapkan bahwa anak-anak usia prasekolah merupakan anakanak yang berada di usia kategori cemerlang di mana dorongan dari berbagai pihak yang ada mengambil peranan penting dalam tugas-tugas formatif tambahan, jika dilihat dari persentase ada sekitar $80 \%$ kemajuan intelektual anak-anak mampu digapai pada usia prasekolah. Usia prasekolah ketika anak (3-6 tahun) serta kemampuan perkembangan pada anak prasekolah ini dapat meliputi perkembangan motorik, personal, sosial dan perkembangan bahasa. Dalam hal perkembangan motorik anak ini didapatkan dua unsur yaitu: motorik kasar dan motorik halus, sementara pada perkembangan personal sosial anak usia prasekolah mencakup aspek yang berhubungan dengan kemampuan melakukan kemandirian, kemudian bersosialisasi dan berintraksi dengan keadaan atau lingkungan sekitarnya. Kemampuan untuk mengaktivasi semua ini diperlukan latihan-latihan, dalam medukung perkembangan dan peningkatan kemampuan anak sehingga kemajuan perkembangan, kemampuan wacana dan bahasa, sosialisasi dan kebebasan anak mampu terbentuk secara ideal sesuai dengan usia anak (Septiani et al., 2016).

Perkembangan sosial dan emosional pada anak diharapkan telah dilakukan semenjak dini 
terutama pada saat ditaman kanakkanan karena pada masa ini anak mulai mengembangkan pergaulanya dan mengikuti apa yang ada disekitar lingkunganya baik disekolah maupun dirumah dimana semua ini akan terbentuk pada usia 5-6 tahun (Nurmalitasari, 2015).

Menurut peneliti usia prasekolah pada anak ialah pada rentan usia 3-6 tahun sehingga proses perkembangan diri anak akan dapat terbentuk dengan baik termasuk kemandirian anak dalam melakukan toilet training.

\section{Kemampuan Toilet training Anak Sebelum di Lakukan Intervensi Konseling dengan Teknik Demonstrasi Pada Anak di TK Lembayung Indah Kota Bengkulu}

Hasil penelitian kemampuan toilet training anak sebelum di lakukan intervensi yang terlihat pada tabel 2 diketahui dari 15 responden sebagian besar responden yaitu 12 orang $(80,0 \%) \quad$ mengalami keterlambatan toilet training sebelum dilakukan intervensi konseling dengan teknik demonstrasi. Hasil ini memperlihatkan bahwa sebelum dilakukan lakukan intervensi konseling dengan teknik demonstrasi sebagian besar anak belum berhasil melakukan toilet training secara mandiri.

Hasil penelitian ini sejalan dengan penelitian yang dilakukan oleh (Kiftiyah et al., 2018) dimana didapatkan hasil pembelajaran sebelum diberikan intervensi demonstrasi terkait toilet training dengan rerata 6,0000 dimana dari 11 komponen pembelajaran terkait toilet training yang paling rendah dalam pembelajaran toilet training ialah suka datang dan pergi sesuka hatinya dengan persentase sejumlah $6 \%$ dengan jawaban iya dan jawaban tidak dengan persentase $93 \%$, minat menggunakan celana dalam bukan popok sebesar $13 \%$ untuk jawaban iya dan $87 \%$ untuk jawaban tidak.

Hasil penelitian ini juga didukung oleh penelitian (Rahayuningsih \& Rizki, 2012) dimana kemampuan toilet training dapat dipengaruhi oleh kemampuan kesiapan seorang anak, kemudian dilakukan pengkajian fisik pada anak dengan tujuan untuk mengetahui sejauh mana kemampuan yang dimiliki oleh anak dalam hal ini terkait kemampuan motorik kasar. Kemampuan motorik ini diharapkan menjadi perhatian khusus karena ketika kemampuan motorik ini berjalan baik keinginan anak untuk melakukan bak akan bekerja dengan baik pula sehingga akan membuat anak merespon melakukan bak dengan benar. Pengkajian kemampuan pola bak dan bab pada anak yang sudah dilakukan secara teratur ini mendukung keberhasilan kemampuan toilet training. selanjutnya kesiapan anak secara intelektual, di tahap ini orang tua berperan untuk mengkomunikasikan tentang bab dan bak, komunikasi yang baik antara orang tua dan anak akan membentuk hubungan yang dapat merangsang anak dalam melakukan toilet training dengan baik atau meningkatkan kemampuan toilet training.

Kondisi lain yang juga menyebabkan kurang optimalnya toilet training pada anak ialah karena kurangnya dukungan dari keluarga dalam hal ini biasanya orang tua tidak konsisten dalam mengulang toilet training di rumah dalam hal ini tidak sabar menunggu perubahan yang dialami anak dalam melakukan toilet training (Saparahayuningsih et al., 2020).

Hasil penelitian yang dilakukan oleh (Subardiah P \& Lestari, 2019) menguangkapkan bahwa setiap anak diharapkan harus melakukan toilet training karena proses ini merupakan tugas perkembangan dari 
seorang anak dengan tujuan agar nantinya anak tidak akan mengalami kondisi mengompol lagi pada usia 45 tahun

Sehingga menurut peneliti untuk rendahnya keterlambatan toilet training pada anak sebelum pemberian intervensi disebabkan karena belum terpaparnya anak terkait pengetahuan, praktik dan pengalaman mengenai pembelajaran toilet training kurangnya dukungan keluarga dalam hal ini orang tua yang berperan penting memberikan pemahaman terkait toilet training yang baik dan benar

\section{Kemampuan Toilet training Anak Setelah di Lakukan Intervensi Konseling dengan Teknik Demonstrasi Pada Anak di TK Lembayung Indah Kota Bengkulu}

Hasil kemampuan toilet training anak setelah di lakukan intervensi dapat dilihat pada tabel 3 dimana dari 15 responden mengalami keberhasilan toilet training setelah dilakukan intervensi konseling dengan teknik demonstrasi. Hasil tersebut menunjukkan bahwa terjadi peningkatan kemampuan toilet training pada anak setelah dilakukan konseling dengan teknik demonstrasi karena dengan dilakukan konseling dengan teknik demonstrasi dapat membuat pengajaran menjadi lebih jelas dan lebih kongkret, sehingga siswa diharapkan lebih mudah dalam memahami apa yang dipelajari.

Hasil penelitian ini sejalan dengan penelitian yang dilakukan oleh (Kiftiyah et al., 2018) dimana diketahui hasil pembelajaran setelah diberikan intervensi demonstrasi terkait toilet training dengan rerata 9,2000 atau megalami peningkatan dibandingkan sebelum pemberian intervensi demonstrasi. Hasil penelitian ini diperoleh dari sebelas komponen pembelajaran terkait toilet training dimana hasil yang tertinggi dengan nilai $100 \%$ diperoleh dari komponen sadar akan tubuh, minat dengan kerapihan, mampu membedakan basah dan kering, mampu mengenal bab dan bak serta menggunakan celana yang mudah dibuka.

Teori lain mendukung hasil penelitian ini mengungkapkan bahwa konseling dapat memberikan tempat bagi orang tua dan anak untuk menyelesaikan permasalahan yang sedang dialami oleh mereka termasuk dalam mencegah terjadinya kegagalan toilet training anak (Sofyan, 2013).

Penelitian lain yang mendukung hasil penelitian ini adalah penelitian yang dilakukan oleh (Astuti \& Demonstrasi, 2015) dimana teknik demonstrasi yang digunakan untuk meningkatkan motivasi anak dalam belajar, yaitu melalui metode demonstrasi dimana anak akan di latih dalam melakukan toilet training, teknik ini diyakini mampu menarik perhatian anak dalam kegiatan berlatih karena menggunakan media yang menarik, sehingga akan terjadi penimgkatan kemampuan toilet training yang baik dan benar. selain itu keberhasilan dari toilet training dipengaruhi dari kesiapan anak menerima pembelajaran dan adanya kerjasama yang baik antara orang tua dengan pemberi materi toilet training serta kebiasaan yang dilakukan kepada anak terhadap kegiatan toilet training yang tentunya kesemua hal ini ada didalam pemberian toilet training yang dilaksanakan secara konseling dengan tehnik demonstrasi (Khoiruzzadi \& Fajriyah, 2019) 


\section{Analisis Bivariat}

\section{Pengaruh Konseling Dengan Teknik Demonstrasi Dalam Meningkatkan Kemampuan Toilet training Anak di TK Lembayung Indah Kota Bengkulu}

Hasil analisis bivariat yang dilakukan dengan menggunakan uji statistik Wilcoxon Signed Ranks Test untuk melihat pengaruh konseling dengan tehnik demonstrasi terhadap kemampuan toilet training didapatkan hasil nilai $\mathrm{p}$ (value) = 0,001 yang berarti $<0,05$, sehingga ada pengaruh konseling dengan teknik demonstrasi dalam meningkatkan kemampuan toilet training anak di TK Lembayung Indah Kota Bengkulu.

Penelitian ini sejalan dengan hasil penelitian yang dilakukan oleh (Zuraidah, 2019) dimana kemampuan persiapan melakukan kegiatan bertoilet bisa dimulai pada anak dengan usia 18 bulan hingga 2 tahun, ketika terjadi pengabaian dalam rentang usia tersebut dalam hal ini persiapan jamban yang bermanfaat akan meningkatkan kemampuan bab dan bak untuk anak -anak. pengabaian ini nantinya akan berdampak pada munculnya kondisi yang disebut masalah kencing yang dikenal dengan enuerisis, kontaminasi banyak urin, susah buang air besar, encopresis dan adanya penolakan untuk pergi ke jamban atau lebih dikenal dengan kemampuan toilet training. Sementara keberhasilan penyiapan jamban kondisi ini tergantung pada kesiapan anak dan keluarga. dalam hal ini kesiapan tersebut dapat dibentuk melalui pemberian pembelajaran seperti toilet training mulai dari persiapan jamban yang dilakukan pada anak kemudian membiasakan anak terkait tandatanda ketika ingin melakukan bab dan bak, serta secara berkelanjutan memberikan contoh bagaimana posisi duduk ketika dijamban sewaktu melakukan toilet training. untuk mendapatkan hasil yang maksimal kegiatan ini dilakukan sekali setiap. Peranan anggota keluarga disini ialah membantu anak untuk buang air kecil ketika keinginan itu muncul di waktu malam hari, diikuti oleh ibu perlu melatih anak untuk melakukan bak satu kali dalam semalam sebelum tidur.

Penelitian lain juga memperkuat hasil penelitian ini yang diungkapkan oleh (Kiftiyah et al., 2018) dimana untuk meningkatkan kemampuan Toilet training pada anak dapat didukung atau ditunjang oleh beberapa intervensi salah satunya dengan melakukan yang dapat di lakukan salah satunya melatih kemampuan toilet training anak dengan menggunakan teknik demontrasi. dimana hasil penelitian tersebut diketahui ada pengaruh peningkatan pembelajaran toilet training dengan menggunakan metode demonstrasi pada anak usia 3 tahun dimana rerata toilet training sebelum intervensi pembelajaran toilet training dengan metode demonstrasi adalah 6,0000 sedangkan setelah diberikan intervensi berupa pembelajaran toilet training dengan metode demonstrasi didapatkan rerata nilai 9,2000 . Hal ini disebabkan metode Demontrasi merupakan wahana untuk memberikan pengalaman belajar agar anak mampu mengusai terkait pemberian materi pembelajaran secara baik. Metode demontrasi membuat anak dapat belajar secara langsung dan mengikuti instruksi yang diberikan oleh pendidik selanjutnya mempraktekkan kegiatan-kegiatan cara toilet training yang baik dan benar. Metode demonstrasi ini memiliki tujuan memberikan kemudahan pemahaman dalam proses Toilet training karena 
diajarkan secara langsung kepada anak.

Hasil penelitian lainya menurut (Rifai, 2017) mengungkapkan hal yang mendukung hasil penelitian ini dimana pembelajaran dengan menggunakan metode demonstrasi akan dapat meingkatkan hasil pembelajaran secara afektif, psikomotor dan kognitif. Sehingga proses pemberian pengetahuan terkait toilet training dengan konseling menggunakan metode demonstrasi akan sangat efektif apalagi ketika diberikan disekolah karena hal ini didukung oleh faktor yang sangat berperan terhadap keberhasilan kegiatan toilet training ialah faktor lingkungan yang sangat dominan dalam mempengaruhi toilet training dalam hal ini lingkungan sekolah yang juga memeiliki peranan penting dalam keberhasilan toilet training (Andriyani et al., 2014).

Penelitian lain yang juga sejalan dengan penelitian ini yaitu penelitian yang dilakukan oleh (Astuti \& Demonstrasi, 2015) menyatakan bahwa peningkaan kemambuan menggunakan toilet dengan menggunakan metode demonstrasi pada anak usia 4-5 tahun di TK Bruder melati Pontianak mampu meningkatkan kemampuan toilet anak dalam melakukan bak, meningkatkan kemampuan anak dalam membersihkan diri setelah bak, meningkatkan kemampuan anak menyiram toilet setalah bak serta meningkatkan kemampuan anal membersihkan tangan setelah bak. Penelitian ini juga menghasilkan perkembangan kemampuan anak dalam toilet training meningkat 95\% setelah diberikan intervensi pembelajaran toilet training dengan teknik demonstrasi.

Teori lain mengungkapkan bahwa bimbingan konseling di sebuah sekolah akan membantu anak dalam mengembangkan kehidupanya mulai dari kehidupan pribadi, sosial, belajar, perencanaan sampai ke pengembangan karir. Proses konseling ini akan mampu memberikan fasilitas bagi anak untuk pengembangan kehidupanya mulai dari kebutuhan, bakat, minat serta konseling mampu membantu menyelesaikan kelemahan dan hambatan yang dialami anak termasuk dalam penerimaan pembelajaran terkait toilet training (PRASETIAWAN, 2016).

Teori lainnya mengungkapkan bahwa pemberian pembelajaran yang dilaksanakan dengan tehnik konseling dapat memberikan tempat bagi orang tua dan anak untuk menyelesaikan permasalahan yang sedang dialami oleh mereka termasuk dalam mencegah terjadinya kegagalan toilet training anak. Sehingga tehnik konseling dengan menggunakan metode demonstrasi atau individu di lakukan dengan proses dimana seorang konselor atau orang tua yang berperan mengarahkan anak sesuai dengan permasalahan yang sedang dialaminya dalam hal ini keterlambatan dalam toilet training anak, mampu menciptakan komunikasi yang baik antara orang tua dan anak dalam mengajarkan toilet training sehingga akan mempengaruhi keberhasilan toilet training. Melalui tehnik ini diharapkan nantinya konselor dan orang tua, anak mampu mendekatkan mendekatkan diri dalam berkomunikasi dengan anak sehingga akan menimbulkan rasa percaya diri dari seorang anak yang sedang mengalami keterlambatan toilet training, sehingga peranan utama untuk memecahkan masalah yang terjadi lebih banyak dilakukan oleh konselor atau pemberi pemebelajaran dengan harapan akhir keterlambatan dari toilet training dapat dicegah, hal ini didasarkan pada bahwa sebuah komunikasi yang baik dan efektif 
mampu peningkatan keamampuan toilet training anak (Sofyan, 2013).

Sementara hasil penelitian lainya yang dilakukan oleh (Agustina \& Sapta, 2015) dimana beberapa faktor yang menyebabkan kegagalan toilet training anak ialah faktor yang kesiapan emosional anak, pola asuh orang tua dan cara mengajarkan toilet training anak. Faktor terkait mengajarkan toilet training pada anak didapatkan hasil berupa $95 \%$ cara mengajarkan toilet training pada anak dengan cara yang salah akan memicu terjadinya keterlambatan anak dalam melakukan toilet training.

Menurut peneliti tehnik konseling dengan model demonstrasi mampu meningkatkan kemampuan toilet training pada anak karena tehnik ini membuat pemberi pembelajaran dalam hal ini perawat akan lebih dekat dengan anak dan orang tua sehingga kedekatan ini mampu menimbulkan kemampuan emosional yang positif dari seorang anak sehingga akan berperan aktif dalam melakukan toilet training, kemudian model demonstrasi memicu anak untuk memiliki pengetahuan yang lebih terkait toilet training karena diajarkan langsung mulai dari tata cara, posisi dan toilet training yang benar sehingga kondisi inilah yang berperan penting dalam keberhasilan dalam pemberian pembelajaran tentang toilet training sehingga mampu meningkatkan kemampuan anak dalam melakukan toilet training yang baik dan benar

\section{KESIMPULAN}

Karakteristik responden dari 15 responden berdasarkan usia di dapatkan sebagian besar responden yaitu 11 orang $(73,3 \%)$ dengan usia 5 tahun. Untuk kemampuan toilet training anak sebelum dilakukan intervensi berupa konseling dengan tehnik demonstrasi didapatkan rata-rata nilai toilet training sebesar 2,13 , sementara kemampuan toilet training setelah dilakukan intervensi berupa konseling dengan tehnik demonstrasi didapatkan rata-rata nilai toilet training sebesar 3,0. Untuk hasil analisis bivariat dengan uji statistik Wilcoxon Signed Ranks Test didapatkan nilai $\mathrm{p}$ (value) $=0,001<$ 0,05 , maka ada pengaruh konseling dengan teknik demonstrasi dalam meningkatkan kemampuan toilet training anak di TK Lembayung Indah Kota Bengkulu.

\section{SARAN}

Berdasarkan hasil penelitian yang telah dilakukan oleh peneliti maka peneliti menyarankan pihak sekolah memberikan pembelajaran khusus mengenai toilet training kepada anak didiknya dengan media yang mudah dipahami oleh anakanak sehingga nantinya anak dapat berhasil melakukan toilet training secara mandiri karena sudah terbiasa melakukan kegiatan tersebut disekolah. Selain itu orang tua diharapkan mengambil peranan penting terkait pembelajaran toilet training yang dapat dilakukan dirumah sehingga menciptakan kemandirian anak dalam melakukan toilet training yang baik dan benar dengan didampngi oleh orang tua

\section{DAFTAR PUSTAKA}

Agustina, W., \& Sapta, R. F. (2015). Tiga Faktor Dominan Penyebab Kegagalan Toilet Training pada Anak Usia 4-6 Tahun. Jurnal Ners Dan Kebidanan (Journal of Ners and Midwifery), 2(2), 188192.

https://doi.org/10.26699/jnk. v2i2.art.p188-192

Andriyani, S., Ibrahim, K., \& Wulandari, S. (2014). Analisis Faktor-Faktor yang 
berhubungan Toilet

Trainingpada Anak Prasekolah. Jurnal Keperawatan

Padjadjaran, v2(n3), 146-153. https://doi.org/10.24198/jkp. $\mathrm{v} 2 \mathrm{n} 3.2$

Astuti, I., \& Demonstrasi, M. (2015). Peningkatan kemampuan penggunaan toilet melalui metode demonstrasi pada anak usia 4-5 tahun. 1-11.

Buston, E. (2018). Kesiapan Fisik Dalam Keberhasilan Toilet Training Pada Balita. Jurnal Media Kesehatan, 10(1), 041044.

https: / /doi.org/10.33088/jmk. v10i1.322

HARDI PRASETIAWAN. (2016). PERAN BIMBINGAN DAN KONSELING DALAM PENDIDIKAN RAMAH ANAK TERHADAP PEMBENTUKAN KARAKTER SEJAK USIA DINI_Angelin Masintan $\mathrm{Br}$ Sitorus_190103001_PKAUD_A. Jurnal CARE (Children Advisory Research and Education), 04, 42-49.

Khoiruzzadi, M., \& Fajriyah, N. (2019). Pembelajaran Toilet Training dalam Melatih Kemandirian Anak. JECED : Journal of Early Childhood Education and Development, 1(2), 142-154.

https://doi.org/10.15642/jece d.v1i2.481

Kiftiyah, K., Wardani, R. A., \& Rosyidah, N. N. (2018). Pengaruh Metode Demonstrasi Tentang Toilet Training Terhadap Peningkatan Pembelajaran Toilet Training Pada Anak Usia 3 Tahun Di Paud I Desa Sooko Kecamatan Sooko Kabupaten Mojokerto. Nurse and Health: Jurnal Keperawatan, 7(1), 71-79. https://doi.org/10.36720/nhjk .v7i1.35

Nurmalitasari, F. (2015).
Perkembangan Sosial Emosi pada Anak Usia Prasekolah. Buletin Psikologi, 23(2), 103. https: //doi.org/10.22146/bpsi. 10567

Rahayuningsih, S. I., \& Rizki, M. (2012). Kesiapan Anak Dan Keberhasilan Toilet Training Di Paud Dan Tk Bungong Seuleupoek Unsyiah Banda Aceh. Kesiapan Anak Dan Keberhasilan Toilet Training Di Paud Dan Tk Bungong Seuleupoek Unsyiah Banda Aceh, 3(3), 274-284.

https: //doi.org/10.52199/inj.v $3 i 3.6527$

Rifai, R. (2017). Penerapan Metode Demonstrasi untuk Meningkatkan Hasil Belajar Pendidikan Agama Kristen Materi Pembelajaran Sakramen Perjamuan Kudus VIII SMP Negeri 17 Surakarta, Tahun 2015/2016. DUNAMIS: Jurnal Penelitian Teologi Dan Pendidikan Kristiani, 1(2), 171. https: //doi.org/10.30648/dun. v1i2.112

Saparahayuningsih, S., Qalbi, Z., \& Indrawati, I. (2020). Sosialisasi Toilet Training Di Desa Taba Baru Kecamatan Taba Penanjung Kabupaten Bengkulu Tengah. Jurnal ABDI PAUD, 1(1), 1-6. https://doi.org/10.33369/abdi paud.v1i1.14037

Septiani, R., Widyaningsih, S., \& Igohm, M. K. B. (2016). Tingkat Perkembangan Anak Pra Sekolah Usia 3-5 Tahun Yang Mengikuti Dan Tidak Mengikuti Pendidikan Anak Usia Dini (Paud). Jurnal Keperawatan Jiwa, 4(2), 114-125. https://jurnal.unimus.ac.id/in dex.php/JKJ/article/view/439 8

Soediono, B. (2014). INFO DATIN KEMENKES RI Kondisi Pencapaian Program Kesehatan 
Anak Indonesia. Journal of Chemical Information and Modeling, 53, 160.

Sofyan S. Willis. (2013). Konseling Individual, Teori dan Praktek. Alfabeta.

Subardiah P, I., \& Lestari, Y. (2019). Hubungan Pemakaian Diapers Selama Toilet Training Dengan Kejadian Enuresis Pada Anak Usia 1-6 Tahun. Jurnal Ilmiah Keperawatan Sai Betik, 14(2), 162.

https://doi.org/10.26630/jkep .v14i2.1300

Sugiyono. (2013). Metode Penelitian Pendidikan Pendekatan Kuantitatif, Kualitatif dan $R \& D$. Alfabeta.

Utami, T. A., Mismadonaria, M., \& Simbolon, A. R. (2020). Hubungan Karakteristik Dan Pengetahuan Ibu Dengan Kemandirian Toilet Training Anak Toddler. Jurnal Bahana Kesehatan Masyarakat (Bahana of Journal Public Health), 4(1), 10-16.

https://doi.org/10.35910/jbkm .v4i1.256

Wasliah, I. (2020). Hubungan

Pengetahuan Ibu Tentang

Toilet Training Dengan

Pelaksanaan Toilet Training

Pada Anak Toddler Di

Kelurahan Karang Pule Kota

Mataram. PrimA : Jurnal Ilmiah

Ilmu Kesehatan, 6(1), 8-13.

https://doi.org/10.47506/jpri. v6i1.161

Zulmiyetri., Nurhastuti., Safaruddin. (2020). PENULISAN KARYA ILMIAH. Kencana. https: / /www.google.co.id/boo ks/edition/Penulisan_Karya_Il $\mathrm{miah} / \mathrm{v} \_32 \mathrm{DwAAQBAJ}$ ?hl=idqgb $\mathrm{pv}=1 \& d q=e k s p e r i m e n+$ menggun akan+rancangan++penelitian+o ne+group+pre-test+dan+posttest\&pg=PA105\&printse $c=$ front cover

Zuraidah, Z. (2019). Hubungan
Penggunaan Diapers Dengan Kemampuan Toilet Training Pada Toodler Di Paud ArRisalah Kota Lubuklinggau Tahun 2017. Masker Medika, 7(1), 19-26. 